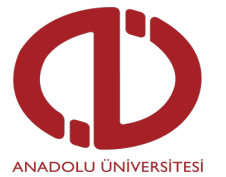

Açıköğretim Uygulamaları ve Araştırmaları Dergisi AUAd

https://dergipark.org.tr/tr/pub/auad

Gönderim: 06.08.2021

Düzeltme: 22.09 .2021

Kabul: 25.10 .2021

Tür: Araştırma Makalesi

\title{
Okul öncesi öğretmenlerinin Covid-19 pandemi sürecinde uzaktan eğitime ilişkin görüşlerinin incelenmesi
}

\author{
Ebru AKTAN ACAR ${ }^{\mathrm{a}}$ \\ Yahya Han ERBAȘ \\ Mustafa Yunus ERYAMAN ${ }^{\mathrm{c}}$ \\ ${ }^{a}$ Çanakkale Onsekiz Mart Üniversitesi, Çanakkale, Türkiye, ORCID: 0000-0002-9944-9013 \\ ${ }^{\mathrm{b}}$ Çanakkale Onsekiz Mart Üniversitesi, Çanakkale, Türkiye, ORCID: 0000-0003-0802-4536 \\ ${ }^{\mathrm{c}}$ Çanakkale Onsekiz Mart Üniversitesi, Çanakkale, Türkiye, ORCID: 0000-0002-4214-1202
}

\begin{abstract}
Özet
Bu araştırmanın amacı, Türkiye'nin farklı bölgelerinde görev yapan okul öncesi öğretmenlerinin Covid-19 pandemi sürecinde öğrenme ve öğretme süreçlerinde yaşamış oldukları deneyimlere dair karşılaştırmalı bir araştırma yapmaktır. Bu amaçlar doğrultusunda okul öncesi öğretmenlerinin, Covid-19 pandemi ilanından sonra uygulanan uzaktan eğitim hakkındaki genel görüşleri ve deneyimleri incelenmiștir. Bu araștırma durum çalıșması ile desenlenmiş bir nitel araștırma olarak tasarlanmıștır. Katılımcılar aktif olarak okul öncesi öğretmeni olarak görev yapan, Türkiye'nin çeşitli bölgelerinden gönüllü olarak katılmayı kabul eden 253 okul öncesi öğretmenidir. Bu çalışma için geliştirilen anket formu ile veriler toplanmıştır. Bulgulara göre, okul öncesi öğretmenleri uzaktan eğitim hakkında çeşitli olumlu, olumsuz ve yansız ifadeler ortaya koymuşlardır. Farklı etkinliklerin kullanımına firsat vermesi, teknoloji bilgisini artırması, veli-öğretmen işbirliği uzaktan eğitim hakkında olumlu ifadelerden bazılarıdır. Odaklanma problemi çıkarması, takipteki güçlük, motor becerilerin gelişimine katkı sunmaması, veli isteksizliği ve veli yetersizliği gibi ifadelerde uzaktan eğitim konusunda olumsuz ifadeler olarak çalışmada yer almaktadır.
\end{abstract}

Anahtar Sözcükler: Okul Öncesi Eğitimi, Uzaktan Eğitim, Covid-19 Pandemisi, Durum Çalışması

\section{An examination of preschool teachers' opinions towards the Covid-19 pandemic process}

\begin{abstract}
The purpose of this research is to conduct a research on the experiences of preschool teachers working in different regions of Turkey in learning and teaching processes during the Covid-19 pandemic. In line with these purposes, the general views and experiences of preschool teachers about distance education after the declaration of the Covid-19 pandemic were examined. This research was designed as a qualitative research patterned with a case study. The participants are 253 preschool teachers who are actively working as preschool teachers and who agreed to participate voluntarily from various regions of Turkey. Data were collected with the questionnaire form developed for this study. According to the findings, preschool teachers put forward various positive, negative and neutral statements about distance education. Allowing the use of different activities, increasing technology knowledge, parent-teacher cooperation are some of the positive statements about distance education. Expressions such as causing focusing problems, difficulty in following up, not contributing to the development of motor skills, unwillingness of parents and inadequacy of parents are included in the study as negative statements about distance education.
\end{abstract}

Keywords: Preschool Education, Distance Education, Covid-19 Pandemic, A Case Study

Aktan Acar, E., Erbaş, Y., H., ve Eryaman, M., Y. (2021). Okul öncesi öğretmenlerinin Covid-19 pandemi sürecinde uzaktan eğitime ilişkin görüşlerinin incelenmesi. Açıöğretim Uygulamaları ve Araştırmaları Dergisi (AUAd), 7(4), 31-54. https://doi.org/10.51948/auad.979726 


\section{Giriş}

Çin Halk Cumhuriyeti'nin Wuhan kentinde ortaya çıkan Covid-19 adı verilen virüsün tüm dünyayı etkisi altına alması sonucunda, 11 Mart 2020 tarihinde Dünya Sağlık Örgütü ([WHO], 2020) pandemi ilan etmiştir. Bu süreçte, dünyanın büyük bir bölümünde birçok sektörde verilen hizmetler durdurulmuştur. Pandeminin ilanıyla olumsuz etkilenen en önemli alanlardan bir tanesi de kuşkusuz eğitimdir. UNESCO (2020)'un yayınladığı rapora göre dünya genelinde 1,6 milyar öğrencinin eğitim hayatı bu durumdan etkilenmiştir. Ülkeler eğitimöğretim faaliyetlerinin durmaması amacıyla uzaktan eğitim başta olmak üzere birçok tedbir kararı almışlardır. Rapora göre, dünya genelinde 826 milyon öğrencinin eğitim-öğretim faaliyetlerinde kullanabileceği herhangi bir teknolojik araca sahip değildir. Ayrıca, uzaktan eğitime dâhil olmanın ön şartı kabul edilen internet bağlantılarındaki yetersizlikler, 56 milyona yakın öğrencinin verilen uzaktan eğitim derslerine bağlanmada sorun yaşamalarına neden olduğu bu raporda belirtilmektedir.

Bunlara ek olarak, yapılan araştırmalar göstermektedir ki uzaktan eğitimin her yaştan ve seviyeden öğrenciye ve bunların ihtiyaçlarına göre baştan sona detaylıca planlanması gereken bir süreçtir (Daniel, 2020). Pandemi döneminin doğurduğu bir diğer sorun ise öğretmen yeterlikleridir. Darling-Hammond ve Hyler (2020)'a göre öğretmenlerin pandemi sürecinin hızlandırdığı uzaktan eğitimin getirdiği yeni rollere mutlak suretle hazır olmalıdırlar.

Teknoloji kullanımın hızla arttığı bir zamanda, çocukların bu araçlara ulaşımı da kolaylaşmıştır. Okul öncesi çağında başlayan bu tanışıklık, çocuğun gelişim özelliklerine uygun ve doğru araçlarla yapılmalıdır (Sayan, 2016). Gün içerisinde birçok etkinlik için tablet, bilgisayar, akıllı telefonlar vb. çocuklar tarafından kullanılmaktadır. Bu araçların yerinde kullanımının çeşitli olumlu yanlarının olduğu bilindiği gibi, gereğinden fazla kullanımına bağlı olarak çocuklarda çeşitli sağlık ve gelişsim sorunlarının ortaya çıktığı araştırmalarla belirlenmiştir (Çalışkan ve Özbay, 2015; Demir ve Özmantar, 2013). Yaşayacakları muhtemel psikolojik ve fizyolojik travmalardan uzak kalmaları, bu dönemde yapılacak doğru planlamalarla mümkün olacaktır (Akkaş-Baysal, Ocak ve Ocak, 2020). Teknoloji kullanımının olumsuz sonuçlarını en aza hatta yok etme boyutuna indirip, olumlu yönlerini ortaya çıkarabilmek Covid-19 pandemi sürecinde daha büyük bir önem kazanmıştır. Bu dönemde okul öncesi öğretmenleri çeşitli programlar, yazılımlar ve Eğitim Bilişim Ağı (EBA) üzerinden, çocukların eğitim öğretim faaliyetlerinden geri kalmamaları için çaba gösterdikleri bilinmektedir. Ebeveyn kontrolünde yapıldığı bilinen bu uzaktan eğitim sürecinde, öğretmenlerin süreci doğru bir şekilde yürütebilmeleri büyük önem kazanmıştır. Eğitim- 
öğretim etkinliklerinin aksamaması adına yürütülen uzaktan eğitim sürecinde, okul öncesi öğretmenlerinin görüşlerini ve deneyimlerini incelemek, ileride yaşanabilecek benzer durumlarda yapılması gerekenleri belirlemede önemli bir durumdur. Bu nedenle yaşanılan Covid-19 pandemisinde okul öncesi öğretmenlerinin deneyimlerinin ve görüşlerinin incelenmesi amaçlanmıştır.

\section{Araştırma Sorunsalı}

$\mathrm{Bu}$ araştırmanın amacı, Türkiye'nin farklı bölgelerinde görev yapan okul öncesi öğretmenlerinin pandemi sürecinde öğrenme ve öğretme süreçlerinde yaşamış oldukları deneyimlere ilişkin bir analiz yapmaktır. Bu amaçlar doğrultusunda aşağıdaki sorulara cevap aranmıştır:

1. Okul öncesi öğretmenlerinin, Covid-19 pandemisi sürecinde uygulanan uzaktan eğitim hakkındaki genel görüşleri ve deneyimleri nelerdir?

1.a. Okul öncesi öğretmenlerinin, uzaktan eğitimin yapılmasının gerekli olduğuna ilişkin görüşleri nelerdir?

1.b. Okul öncesi öğretmenlerinin, uzaktan eğitimin yapılmamasının gerekli olduğuna ilişkin görüşleri nelerdir?

2. Okul öncesi öğretmenlerinin, uzaktan eğitimde veli katılımına ilişkin düşünceleri nelerdir?

\section{İlgili Alanyazın}

Ülkemiz dahil dünyanın birçok yerinde, öğretmenlerin, eğitimi yönetenlerin, velilerin ve özellikle öğrencilerin Covid-19 pandemi sürecine ne kadar hazır olduklarına ilişkin yapılan araştırmalar hızla artmaktadır (Demir ve Özdaş, 2020; Fauzi ve Khusuma, 2020; Garbe vd., 2020; Kim, 2020; Korkmaz ve Toraman, 2020; Reimers ve Schleicher, 2020; Sirem ve Baş, 2020). Yapılan bu çalışmalarının sonuçları incelendiğinde; pandemi sürecine hazırlıksız yakalanmak, kullanılan yazılımlara ilişkin bilgi ve deneyim eksiklikleri, öğrencilerle etkili iletişim kuramamak, kullanılan materyalleri yeni duruma uygun hale getirmemek, dersleri kontrolde güçlükler yaşamak, yalnızlık hissinin artması ve fırsat eşitsizliği Covid-19 pandemisinin eğitim üzerinde bıraktığı olumsuz etkiler olarak belirlenmiştir.

$\mathrm{Bu}$ araştırmanın merkezinde yer alan okul öncesi eğitiminin, pandemi döneminde uzaktan eğitimden nasıl etkilendiğine dair araştırmalar incelendiğinde, sonuçların yukarıda belirtilenlerden farklı olmadığı görmekteyiz görülmektedir. Örneğin, Can (2020) yaptığ1 
çalışmada, Türkiye'de uzaktan eğitim uygulamasında kullanımı artan Eğitim Bilişim A $\breve{g} 1$ (EBA) sisteminin sınırlı düzeyde kaldığını, özellikle okul öncesi öğrencilerine yönelik içeriğin yetersiz olduğu sonucuna ulaşmıştır. Benzer şekilde, İnan (2020) birçok alanda uzaktan eğitimin yetersiz kaldığını ve bundan en az seviyede etkilenmeleri önemli olduğunu belirtmiş, okul öncesi eğitiminin yeniden yapılandırılmasını tavsiye etmiş̧tir. Tarkoçin, Alagöz ve Boğa (2020) ise yaptıkları araştırmada pandemi sonrası okul öncesi çocuklarının dijital araçları kullanım sıklığının daha da arttığını ve çocukların rutinlerinin bozulmasına bağlı olarak "kaygı, korku, agresif/öfkeli/saldırgan davranışlar, aşırı hareketlilik, kardeş kıskançlığı, anne-babaya bağımlılık” (s.1033) gibi olumsuz durumların ortaya çıktı̆̆ını belirlemişlerdir.

Çocuğun gelecekteki akademik başarılarını önemli ölçüde etkileyeceği bilinen okul öncesi eğitimde çocuğun yaşayacağı sorunlar, ileride birçok olumsuz durumla karşılaşmasına neden olabilmektedir. Schweinhart'a (2020) göre kaliteli erken çocukluk eğitiminden geçen çocukların gelişimi ve eğitimi olumlu yönde etkilenir. Yaşanan bu pandemi döneminde, çocukların aldığı uzaktan eğitimin, bu eğitimi vermekle yükümlü olan okul öncesi öğretmenlerinin görüşlerinin ve deneyimlerinin incelenmesi, ilerleyen dönemde uzaktan eğitimin kalıcı bir hale gelmesine ihtimaline karşı alınması gereken tedbirlerin belirlenmesi adına önem arz etmektedir.

\section{Yöntem}

$\mathrm{Bu}$ araştırma nitel araştırma modeline uygun, durum çalışması olarak desenlemiştir. Nitel araştırma "gözlem, görüşme, doküman analizi gibi nitel veri toplama yöntemlerinin kullanıldığı, algıların ve olayların doğal ortamda gerçekçi ve bütüncül bir biçimde ortaya konmasına yönelik nitel bir sürecin izlendiği”" (Yıldırım ve Şimşek, 2018, s.41) bir araştırma türü olarak açıklanmaktadır. Durum çalışması bir ya da birden fazla durumun detaylandırılarak incelenmesi ve "bir duruma ilişkin etkenler (ortam, bireyler, olaylar, süreçler vb.) bütüncül bir yaklaşımla araştırılması ve ilgili durumu nasıl etkiledikleri ve ilgili durumdan nasıl etkilendikleri üzerine odaklanılması" (Yıldırım ve Şimşek, s.73) olarak açıklanmaktadır. Bu çalışma Covid-19 nedeniyle ülke genelinde verilen uzaktan eğitime ilişkin okul öncesi öğretmenlerinin görüşlerinin incelenmesi hedeflendiğinden durum çalışması desenine uygun olarak planlanmıştır. 


\section{Katılımcılar}

Araştırmada amaçsal örneklem yaklaşımının kartopu örnekleme yöntemi kullanılmıştır (Büyüköztürk vd.,2020, s.92; Creswell,2012, s.209). Bu örneklem yöntemine göre, araştırmacı çalışmanın amacına uygun katılımcılardan bir kısmına ulaşır ve bu katılımcıların amaca uygun diğer katılımcıları önermeleriyle katılımcı sayısını arttırmaktadır. Çalışmanın katılımcıları aktif olarak okul öncesi öğretmeni olarak görev yapan, Türkiye'nin çeşitli bölgelerinden gönüllü olarak katılmayı kabul eden 253 kişiden oluşmaktadır. Hazırlanan çevrimiçi formu önce 308 kişinin doldurduğu tespit edilmiştir. Sorulara verilen cevapların sorularla uyumsuz olduğu, soruların bir ya da birkaçına yanıt vermeyen katılımcıların görüşleri çalışmaya dahil edilmemiştir. Kullanılmasında sakınca görülmeyen formları dolduran öğretmenler, OÖ1, OÖ2, OÖ3,...., OÖ253 şeklinde gerçek isim verilmeden kodlanmıştır. Katılımcıların demografik bilgileri tablo 1'de verilmiştir.

\begin{tabular}{|c|c|c|c|}
\hline \multicolumn{4}{|c|}{$\begin{array}{l}\text { Tablo } 1 \\
\text { Katılımcıların Demografik Özellikleri }\end{array}$} \\
\hline Özellikler & & $N$ & $\%$ \\
\hline \multirow[t]{2}{*}{ Cinsiyet } & Erkek & 24 & 9,5 \\
\hline & Kadın & 229 & 90,5 \\
\hline \multirow[t]{6}{*}{ Mesleki Kıdem } & İlk yıl & 18 & 7,1 \\
\hline & 2-5 Yil Arası & 46 & 18,2 \\
\hline & 6-10 Y1l Arasi & 56 & 22,1 \\
\hline & 11-15 Yıl Arası & 60 & 23,7 \\
\hline & 16-20 Yil Arası & 26 & 10,3 \\
\hline & 21 Yildan Fazla & 47 & 18,6 \\
\hline \multirow[t]{2}{*}{ Bağlı Bulunduğunuz Kurum } & Resmi Kurum & 198 & 78,3 \\
\hline & Özel Kurum & 55 & 21,7 \\
\hline \multirow[t]{2}{*}{ Eğitim Seviyesi } & Lisans & 209 & 82,6 \\
\hline & Yüksek Lisans & 44 & 17,4 \\
\hline Toplam & & 253 & 100 \\
\hline
\end{tabular}

Tablo 1'e baktığımızda, katılımcı okul öncesi öğretmenlerinin 229(\%90,5)'u kadın, 24(9,5)'ü erkek öğretmenlerdir. Meslek kıdemine göre öğretmenlerimizi incelediğimizde, en yüksek katılım mesleğinin 11-15 yıl aralığında çalışan okul öncesi öğretmenleri (n=60, \%23,7) olurken, en az katılımın mesleğinde 16-20 yıl arasını çalışan okul öncesi öğretmenleri (n=26, $\% 10,3)$ olduğu görülmektedir. Resmi kurumlarda görev yapan okul öncesi öğretmenleri 
\%78,3'le (n=198), özel kurumlarda görev yapan okul öncesi öğretmenlerine göre ( $\mathrm{n}=55$, \%21,7) daha fazla katılım göstermişlerdir. Eğitim seviyelerine göre katılımcılarımızı incelediğimizde, lisans mezunu okul öncesi öğretmenleri $(n=209, \% 82,6)$, yüksek lisans mezunlarına göre $(\mathrm{n}=44, \% 17,4)$ daha fazla katılım göstermişlerdir.

\section{Veri Toplama Aracı}

Bu çalışmanın özelinde geliştirilen yazılı görüş formu ile veriler toplanmıştır. Çalışmada yer alan sorular, çeşitli demografik bilgiler ile okul öncesi öğretmenlerinin uzaktan eğitimle ilişkin görüşlerini incelemek amacıyla oluşturulan sorulardan oluşmaktadır. Bu çalışmaya özgü geliştirilen yazılı görüş formuna ait sorular, katılımcıların demografik özellikleri belirlemeye yarayan olgusal, katılımcıların bir konudaki bilgilerini belirlemek için bilgi sorularından oluşturulmuştur (Büyüköztürk vd., 2020). Bu soru şekilleri göz önünde bulundurularak, araştırmada okul öncesi öğretmenlerinin Covid-19 pandemisinde uygulamaya konan uzaktan eğitim sürecinde ilişkin deneyimleri ile ilgili görüşlerini incelemek amaciyla geliştirilen sorular kullanılmıştır.

\section{Verilerin Toplanması}

Araştırmacılar tarafından oluşturulan anket formu, çalışmaya katılmaya gönüllü okul öncesi öğretmenlerine 20.12.2020-30.12.2020 tarihleri arasında oluşturulan çevrimiçi form aracılığıyla ulaştırılmıştır. Burada gelen görüşlerle beraber araştırmacılar analiz sürecine başlamış olup, sık tekrarların olmaya başladığı fark edildikten sonra veri doygunluğu sağlandığı düşünüldüğünden, veri kabulü durdurulmuştur.

\section{Verilerin Analizi}

Bu çalışmanın verileri içerik analizi ile değerlendirilmiştir. İçerik analizinin tümevarımcı analiz yaklaşımıyla incelenen veriler, Yıldırım ve Şimşek (2018) tarafından belirlenen;(i) verilerin kodlanması, (ii)temaların bulunması, (iii)verilerin kodlara ve temalara göre düzenlenmesi ve (iv) bulguların yorumlanması (ss.243-251) basamakları takip edilerek analiz edilmiştir. MAXQDA programı kullanılarak yapılan bu işlemlerden sonra elde edilen kodlarla, görsel bir şekilde kodların yoğunluğunun gösterilmesi amacıyla kelime bulutları (word cloud) oluşturulmuştur. Daha sonra kodların bir araya gelmesiyle oluşan temalar tablolar halinde sunulmuştur. 


\section{Geçerlik ve Güvenirlik}

Açık uçlu anket soruları Covid-19 dönemine ilişkin karşılaşılması mümkün durumlar göz önünde bulundurularak hazırlanmıştır. Katılımcı teyidi ve uzman incelemesi ile geçerlik ve güvenirliği belirlenmiştir. Analizler ile ortaya çıkan temalar, alt temalar ve kodlar araştırmada yer alan araştırmacılar tarafından ve iki farklı alan uzmanının incelemesi ve alınan geri bildirimlerle benzerlikler ve farklılıklar ortaya konulmuştur. Ortaya çıkan farklılıklar konusunda görüşmeler yapılarak ortak bir düşüncede buluşma sağlanıp, daha sonra öğretmen görüşlerine başvurulmuştur. Dokuz aktif olarak görev yapan okul öncesi öğretmeni bu dönemde ortaya çıkan durumlara ilişkin oluşturulan temaları, alt temaları ve kodları inceleyerek, bunların uygun olup olmadığı konusunda düşüncelerini bildirmişlerdir. Bulgular kısmında katılımcı okul öncesi öğretmenlerinin beyan ettikleri fikirlerden direkt alıntılarla geçerlik ve güvenirlik sağlanmak istenmiştir.

\section{Bulgular ve Yorumlar}

\section{Uzaktan Eğitime Dair okul Öncesi Öğretmenlerinin Görüşleri ve Deneyimleri}

Araştırmanın birinci alt probleminde okul öncesi öğretmenlerinin uzaktan eğitim sürecine ilişkin görüşleri ve deneyimleri incelenmiş olup, elde edilen kodlar şekil 1'deki gibi gösterilmektedir.

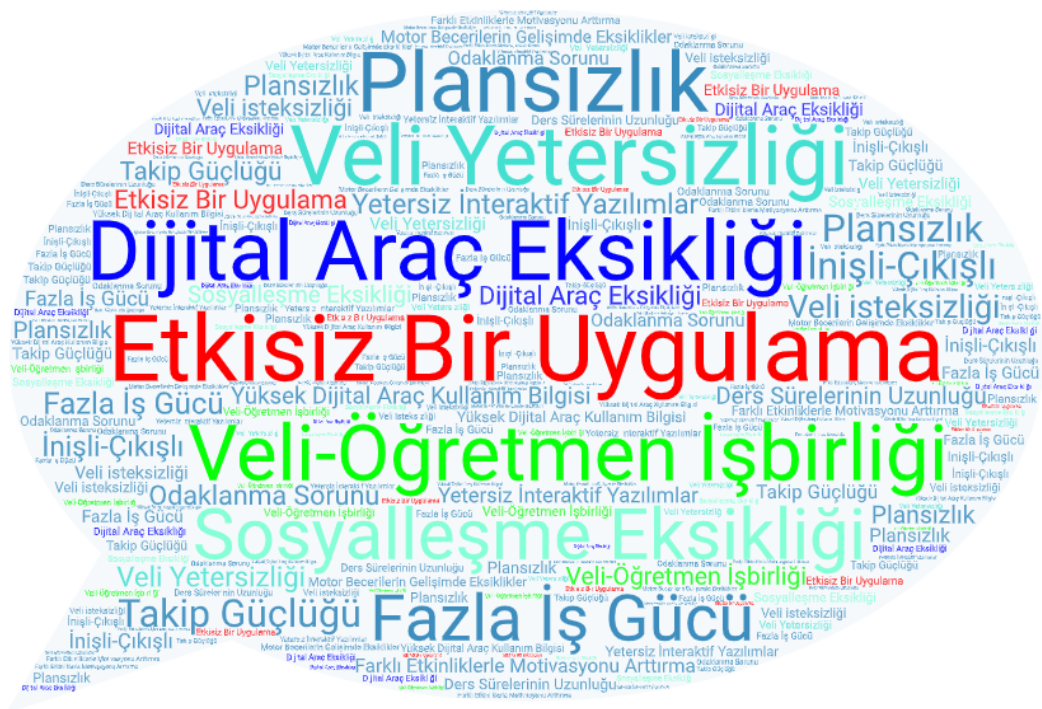

Şekil 1. Okul öncesi öğretmenlerinin uzaktan eğitime ilişkin genel görüşlerinin kod dağılımı 
Şekil 1'de okul öncesi öğretmenlerinin uzaktan eğitim sürecine ilişkin görüşlerinin ve deneyimlerinin incelenmesiyle ortaya çıkan kelime bulutu yer almaktadır. Kelime bulutları oluşturulurken görüşlerde en fazla yer alan ifade, diğerlerine göre daha büyük puntolarla gösterilerek, katılımcıların görüşlerinin en çok hangi kavram etrafında döndüğünü göstermek amaçlanmaktadır. Buradan yola çıkarak, okul öncesi öğretmenlerinin uzaktan eğitimi etkisiz olarak gördüklerine ilişkin görüşlerin ağır bastığı çıkmaktadır. Tablo 2'de bu görüşlerden elde edilen alt temalar ve temalar yer almaktadır.

\begin{tabular}{|c|c|c|c|c|}
\hline Temalar & Alt temalar & Kodlar & f (Kod Sayısı) & $\%$ \\
\hline \multirow{7}{*}{$\begin{array}{l}\text { Eğitim-Öğretim } \\
\text { Etkinliklerinden } \\
\text { Kaynaklı Durumlar }\end{array}$} & \multirow[t]{4}{*}{ Olumsuz İfadeler } & Etkisiz Bir Uygulama & 140 & 30,6 \\
\hline & & Odaklanma Sorunu & 14 & 3,1 \\
\hline & & Takip Güçlüğg̈ü & 17 & 3,7 \\
\hline & & $\begin{array}{l}\text { Motor Becerilerin } \\
\text { Gelişiminde Eksiklikler }\end{array}$ & 19 & 4,1 \\
\hline & \multirow[t]{3}{*}{ Olumlu İfadeler } & $\begin{array}{l}\text { Farklı Etkinliklerle } \\
\text { Motivasyonu Arttırma }\end{array}$ & 17 & 3,7 \\
\hline & & $\begin{array}{l}\text { Yükssek Dijital Araç } \\
\text { Kullanım Bilgisi }\end{array}$ & 21 & 4,6 \\
\hline & & Veli-Öğgretmen İşbirliği & 28 & 6,1 \\
\hline \multirow{6}{*}{$\begin{array}{l}\text { Yetkililerden } \\
\text { Kaynaklı Durumlar }\end{array}$} & \multirow[t]{5}{*}{ Olumsuz İfadeler } & Plansızlık & 21 & 4,6 \\
\hline & & Ders Sürelerinin uzunluğu & 19 & 4,1 \\
\hline & & $\begin{array}{l}\text { Yetersiz İnteraktif } \\
\text { Yazılımlar }\end{array}$ & 21 & 4,6 \\
\hline & & Dijital Araç Eksikliği & 37 & 8,1 \\
\hline & & Fazla İş Gücü & 23 & 5,0 \\
\hline & Yansız İfadeler & İnişli-Çıkışlı & 12 & 2,6 \\
\hline \multirow{2}{*}{$\begin{array}{l}\text { Aileden Kaynaklı } \\
\text { Durumlar }\end{array}$} & \multirow[t]{2}{*}{ Olumsuz İfadeler } & Veli İsteksizliği & 17 & 3,7 \\
\hline & & Veli Yetersizliği & 24 & 5,2 \\
\hline $\begin{array}{l}\text { Toplumdan Kaynaklı } \\
\text { Durumlar }\end{array}$ & Olumsuz İfadeler & Sosyalleşme Eksikliği & 28 & 6,1 \\
\hline Toplam & & & 458 & 100,0 \\
\hline
\end{tabular}

Okul öncesi öğretmenlerinin uzaktan eğitime dair genel görüşlerinin yer aldığı birinci araştırma sorusunun bulgularını incelediğimizde, öğretmenlerimizin bu sürece ilişkin olumlu, 
olumsuz ve yansız ifadelere yer verdiğini görmekteyiz. Burada ortaya çıkan kodlar "EğitimÖğretim Etkinliklerinden Kaynaklı Durumlar, Yetkililerden Kaynaklı Durumlar, Aileden Kaynaklı Durumlar ve Toplumdan Kaynaklı Durumlar" olmak üzere dört ana tema altında toplanmıştır. Bu sürece ilişkin en olumlu görüşün "veli-öğretmen işbirliği $(n=28, \% 6,1)$ " olduğunu, en olumsuz görüşün ise "etkisiz bir uygulama $(n=140, \% 30,6)$ " olduğunu görmekteyiz. Öğretmenlerimizin bazılarına ait görüşler aşağıdaki gibidir:

“Erken çocukluk döneminde esas olan uzaktan eğitim döneminde çocuğun arkadaşları ve ögrretmenleri ile duygusal bă̆ının devamlılı̆̆ını să̆lamak ve güvende mutlu hissetmesini să̆lamaktır, bu yaş grubunu saatlerce bilgisayar başında sabit tutmak onların enerjilerine ters bir durum olacaktır, o yüzden olabildiğince aktif ve saatleri çok uzun olmayan bir online eğitim sistemi kurulmalı.” (OÖ114, K)

"Okul öncesi için uzaktan eğitim çok sikıntılı bir süreç. Çocukların dikkat sürelerini ve çabuk sıkılmalarını düşünürsek bu yaş grubu için uzaktan eğitim çok da verimli sayılamaz. Geçen dönem yaptı̆̆ım uzaktan ĕgitim çalışmalarına dayanarak veli isteğinin de çok önemli olduğunu düşünüyorum. Çünkü çocuk istekli ve öğrenmeye açık olsa bile veli katılım să̆lamıyorsa ne yazık ki çocuk uzaktan eğitimden mahrum kalıyor.” (OÖ150, K)

"Uzaktan ĕgitimde öğrencilerim çok mutlu oluyorlardı ve katılım çok iyiydi. Her gece etkinliklerimizi yapıyor, sohbet ediyor ve hikayemizi okuyordum. Okul öncesi döneme canlı ders konulabilir. Ben zoom programından yaptım.” (OÖ199, E)

“Ĕ̆gitim iletişim gerekli derslerde arkadaşlarını öğretmenini görüp mutlu olduklarını gözlemliyorum. Evden dışarı çıkamadıklarından bu yöntemle en azından moral motivasyon oldu.” (OÖ212, K)

Görüldüğü üzere katılımcılar ders sürelerinin çok uzun tutulmasının çeşitli becerilerin gelişimine olumsuz etki göstereceğini, bununla beraber bu pandemi sürecinde sosyalleşme yolu olarak uzaktan eğitimin kullanılabileceğine değinmişlerdir. Özellikle veli katılımının desteklenmesinin, bu süreçte ortaya çıkabilecek muhtemel sorunları azaltacağına ilişkin görüş bildirmişlerdir.

\section{Uzaktan Eğitimin Neden Yapılması Gerektiğine İlişkin Okul Öncesi Öğretmenlerinin Görüsşleri}

Araştırmanın birinci alt probleminin ilk bölümünde okul öncesi öğretmenlerinin uzaktan eğitimin neden yapılması gerektiğini belirten ilişkin görüşleri ve deneyimleri incelenmiş olup, elde edilen kodlar şekil 2'deki gibi gösterilmektedir. 


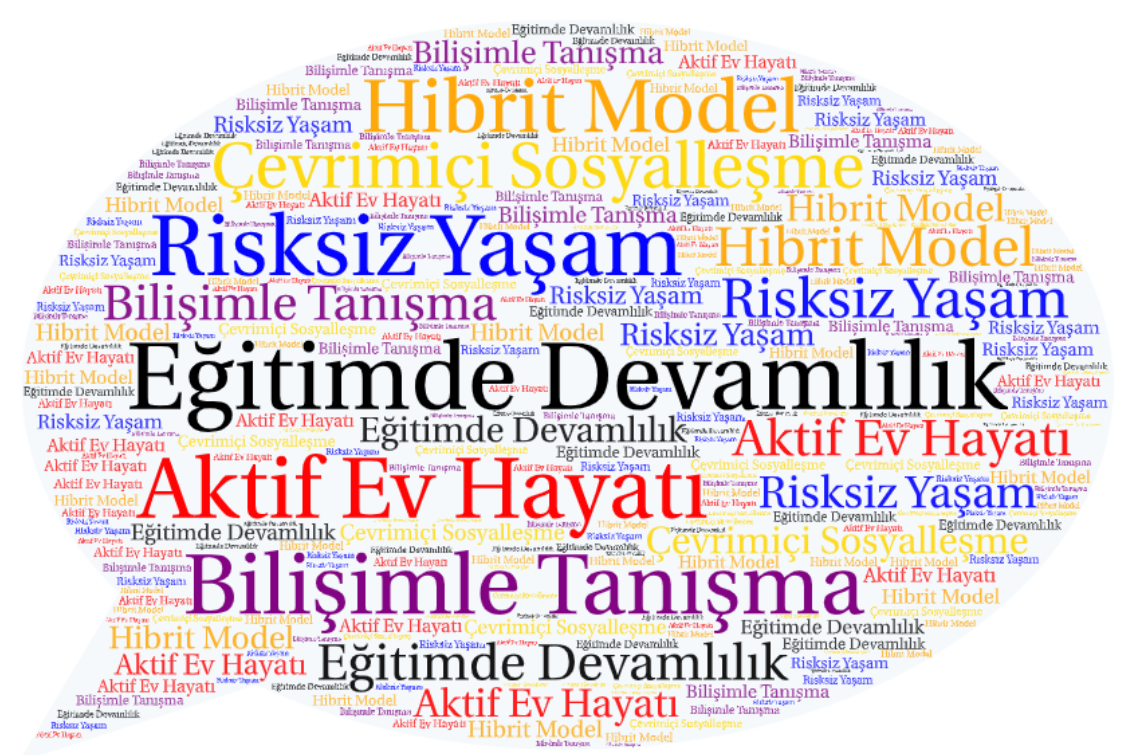

Şekil 2. Okul öncesi öğretmeninin uzaktan eğitim yapılmasına ilişkin kodların dağılımı

Şekil 2'de yer alan kodları incelendiğinde okul öncesi öğretmenlerinin uzaktan eğitimin, eğitimde devamlılığın önemli olmasından dolayı uygulanması gerektiğini belirten görüş, diğerlerinden daha fazla belirtilmiştir. Tablo 3'te bu görüşlerden elde edilen kodların birleşmesiyle elde edilen temalar yer almaktadır.

\section{Tablo 3}

Okul Öncesi Öğretmenlerinin Uzaktan Ĕ̆itimin Neden yapılması Gerektiğine İlişkin Düşünceleri

\begin{tabular}{|l|l|l|l|}
\hline Temalar & Kodlar & $\mathrm{f}($ Kod Sayısı) & $\%$ \\
\hline \multirow{3}{*}{ Teknoloji Temelli Gerekçeler } & Hibrit Model & 20 & 6,1 \\
\cline { 2 - 4 } & Bilişimle Tanışma & 26 & 7,8 \\
\hline \multirow{3}{*}{ Toplumsal Temelli Gerekçeler } & Aktif Ev Hayatı & 65 & 19,5 \\
\cline { 2 - 4 } & Çevrimiçi Sosyalleşme & 26 & 7,8 \\
\cline { 2 - 4 } & Risksiz yaşam & 91 & 27,5 \\
\hline Eğitim Temelli Gerekçeler & Eğitimde Devamlılık & 104 & 31,3 \\
\hline Toplam & & 332 & 100 \\
\hline
\end{tabular}

Okul öncesi öğretmenlerinin uzaktan eğitimin neden yapılması gerektiğine ilişkin görüşleri incelediğinde, bu modelin eğitimde devamlılı̆̆ın esas olması ve bunu gerçekleştirmek adına uzaktan da olsa eğitimin devam etmesi gerektiği, teknolojik araçların eğitim amaçlı 
kullanımıyla tanışmak adına güzel bir fırsat olduğunu, evde kalınması gerektiği bu dönemde aktif olarak çocukların bir uğraşının olacağını, internet aracılığıyla olsa da bir sosyalleşmenin olacağı, çocukların yalnızlaşmayacağı, ne olursa olsun sağlığın riske atılacak bir durum olmadığını ve çocukların evden eğitim alabileceğini, son olarak eğitimi desteklemesi adına bazen sınıf içi bazen sınıf dışı uygulamalarla hibrit olarak uygulanması gerektiğini belirten görüşler ortaya koymuşlardır. Okul öncesi öğretmenlerinin bu görüşlerinden bazıları aşağıda gösterilmiştir:

“3-5 yaş aralı̆̆ındaki çocuklar pandemi döneminde evde ilgisiz ve asosyal kallyor, internette kontrolsüzce çok vakit geçiriyor. Bu dönem çocuklarının ĕgitimleri konusunda velilerin desteklenmesi ve uzaktan ĕ̆itimlerin aksatılmaması gerekir.” (OÖ3, K)

“Çă̆ımızda çocuklar bilişim teknolojisini zaten sıklıkla kullanıyor ve dünya da ĕ̆itim bence bu yöne do ğru ilerliyor. En azından çocuklar bu ă̆ yararlı kullanabilsin.” (OÖ54, K)

“Okul öncesi e ğitimde sosyal mesafe-maske-hijyen kuralı uygulamak çok zordur. Hijyen kısmi olarak belki ama di ğerleri hastalığın yayılarak taşınmasına sebep olur. Bu nedenlerle bu süreçte uzaktan ĕgitimle çocuklarımıza ulaşmalıyı.” (OÖ61, K)

“Bu dönemde ne öğretmenleri ne de öğrencileri riske atmamalıyı. Hastanelerin kapasitesi belli. Çocuklarımı çok özledim ancak kronik hastalığı olan bir insan olarak hem kendinin hem ailemin hem çocukların sağlı̆̆ından endişe ediyorum.” (OÖ69, K)

“Okul bă̆ını koparmamak, öğretmen öğrenci ve arkadaş iletişimindeki paylaşımları için yapılabilir. Bilişsel gelişimini destekliyor. Yaş gelişimine uygun etkinlik seçimi önemli.” (OÖ99, K)

“Hayatın gerçeğine să̆llktan daha önemli bir olgu yoktur. Pandemi dönemi tüm dünyayı eş zamanlı olarak tüm yaş grubunu etkilemiştir. İnsanoğlu yeni duruma uyum să̆layabilme gücüne sahiptir. Öğretmen ve ögrenci de birey olarak öncelikle kendini güvende hissetme ihtiyacına sahiptir. Ekran karşısından da olsa öncelikle güçlü bă̆ kurulmalı, alanında yetkin ögretmenler iyi bir planlama ile öğretim sürecine ortaklık etmelidir.” (OÖ115, K)

“Çocuklar hiç ĕğitim almamış olmasından iyidir diye düşündüğümden. Ayrıca dijital ortamda bile olsa akranları ile bir araya gelmeleri çocukları duygusal olarak destekleyecektir. Kısa süreli eğitim aralıkları ile de olsa azıcık okul disiplinine kavuşacaklardır” (OÖ119, K)

“Henüz sonuçları ya da gidişatının ne olacağını bilmediğimiz, tüm Dünya'yı durduran bir hastalık ile baş etmeye çalışlyoruz. Böyle bir dönemde okula dönüşün özellikle Avrupa ülkelerinde negatif geri dönüşleri olduğu da bir gerçek. Çocuklar en korunmasız gruptalar. Kendileri hasta olmasalar dahi taşıyıcı olmaları bu kararda büyük rol oynuyor.” (OÖ127, E) 
“Evet olması gerektiğini düşünüyorum. Küçük yaş grubu ile çalıştı̆̆ımız için geçen 5 buçuk 6 ay kadar olan bu süre çocukların sınıf ortamından ve arkadaşlarından uzaklaşmaları için yeterli olduğundan geçen her gün çocukları biraz daha okuldan uzaklaştırdı̆̆ını ve uyum problemi ile karşılaşmamızı güçlendirdiğini düşünmekteyim.” (OÖ168, K)

“Yaşamı sürdürebilmek için bir amaç gerekli. Ö ğrencinin heyecan duyacă̆ı bir program düzenlenirse, öğrenci kendi sorumluluklarını alarak ĕgitime kısmen de olsa devam eder. Akademik beklentiyi düşük tutarak bol etkinlikli, paylaşımlı çalışmalar yapılmalı. Ancak ilkokulda aile deste ği şart.” (OÖ194, K)

“Erken çocukluk dönemindeki çocukların kendilerini koruyabilecek şekilde maske mesafe ve hijyen şartlarını sağlayabileceklerini düşünmüyorum. Ayrıca belirtisiz olarak taşıyıcı olmanın ihtimali olan çocukların hastalı̆̆ın yayılmasında büyük rol oynayacă̆ını düşünüyorum bu yüzden uzaktan e ğitim olmalı.” (OÖ220, K)

$\mathrm{Bu}$ görüşler incelendiğinde, okul öncesi öğretmenlerinin dijital araçlarla erken yaşta tanışıldığının farkında olduklarını, böylece Covid-19 pandemi sürecinde bu tanışmanın avantaja dönüştürebileceğine ilişkin görüşler bildirmişlerdir.

\section{Uzaktan Eğitimin Neden Yapılmaması Gerektiğine İlişkin Okul Öncesi}

\section{Öğretmenlerinin Görüşleri}

Araştırmanın birinci alt probleminin ikinci bölümünde, okul öncesi öğretmenlerinin uzaktan eğitimin neden yapılmaması gerektiğini belirten ilişkin görüşleri ve deneyimleri incelenmiş olup, elde edilen kodlar şekil 3'teki gibi gösterilmektedir.

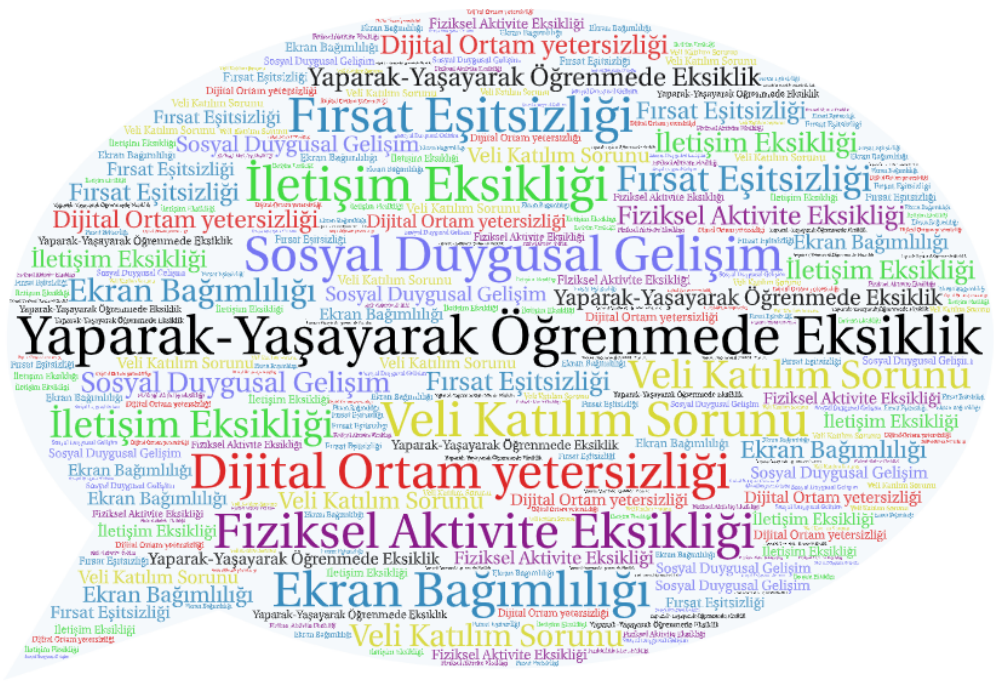

Şekil 3. Okul öncesi öğretmeninin uzaktan eğitim yapılmamasına ilişkin kodların dağılımı 
Şekil 3’te görüldüğü üzere, uzaktan eğitimin yapılmaması gerektiğini belirten okul öncesi öğretmen görüşlerinin büyük bir çoğunluğu yaparak-yaşayarak öğrenmedeki eksiklikler görüşünün etrafında toplanmıştır. Tablo 4 'te bu görüşlerden elde edilen kodların birleşmesiyle elde edilen temalar yer almaktadır.

\begin{tabular}{|c|c|c|c|}
\hline \multicolumn{4}{|l|}{$\begin{array}{l}\text { Tablo } 4 \\
\text { Okul Öncesi Ö ğretmenlerin } \\
\text { Düşünceleri }\end{array}$} \\
\hline Temalar & Kodlar & f (Kod Sayısı) & $\%$ \\
\hline Teknoloji Temelli Gerekçeler & Dijital Ortam yetersizliği & 39 & 31,3 \\
\hline \multirow[t]{2}{*}{ Toplumsal Temelli Gerekçeler } & Firsat Eşitsizliği & 18 & 6,3 \\
\hline & Ekran Bağımlılı̆̆ı & 18 & 6,3 \\
\hline \multirow[t]{3}{*}{ Eğitim Temelli Gerekçeler } & Yaparak-Yaşayarak Öğrenmede Eksiklik & 62 & 21,5 \\
\hline & Fiziksel Aktivite Eksikliği & 22 & 7,6 \\
\hline & Sosyal Duygusal Gelişim & 44 & 15,3 \\
\hline \multirow[t]{2}{*}{ Aile Temelli Gerekçeler } & Veli Katılım Sorunu & 54 & 18,8 \\
\hline & İletişim Eksikliği & 31 & 10,8 \\
\hline Toplam & & 288 & 100 \\
\hline
\end{tabular}

Okul öncesi öğretmenlerinin uzaktan eğitimin neden yapılmaması gerektiğine dair görüşlerini incelediğimizde, öğrencilerin yeterince dijital araçlara sahip olmadığını, fırsat eşitsizliğine neden olduğunu, ekran bağımlılığını arttırdığını, okul öncesi eğitimin temellerinden olan yaparak-yaşayarak öğrenme eksikliğinin olduğunu, fiziki etkinliklerin yapılamamasını, çocukların hem sosyal hem de duygusal gelişimlerine darbe vurduğunu, velilerin yeterince katılım göstermeyerek eğitimi sekteye uğrattıklarını ve iletişim kurmada çok ciddi sıkıntıların yaşandığını belirten görüşler ortaya atmışlardır. Okul öncesi öğretmenlerinin bu görüşlerinden bazıları aşağıda gösterilmiştir:

“Erken çocukluk e ğitimi okulda yaparak yaşayarak anlam kazanacă̆ııı düşünüyorum. Somut yaşantı yaratılmalı diye düşünüyorum.” (OÖ1, K)

“Oyunla öğrenme dönemindeki çocukları ekran başında saatlerce oturtup birbirlerini görmeden sınıf ortamı kurmaya çalışmak mümkün değildir.” (OÖ12, K)

“Uzaktan çocuğun konsantrasyonu să̆lanamadı̆̆ için çok verimli olmadı̆̆ını düşünüyorum.” (OÖ26, K) 
“Oyunla ögrrenme dönemindeki çocukları ekran başında saatlerce oturtup birbirlerini görmeden sınıf ortamı kurmaya çalışmak mümkün de ğildir” (OÖ30, K)

"Okul öncesi dönemde her gün uzaktan eğitim yapmak hem çocukları hem aileleri hem de ögrretmenleri olumsuz etkileyecektir diye düşünüyorum.” (OÖ51, K)

Uzaktan eğitim yapılması çok zorlu bir süreç ve bu sürecin etkili olduğunu düşünmüyorum. Ne yazık ki köylerde ulaşamadı ̆̆ımız birçok çocuk var. Dönüşümlü olarak yüz yüze e ğitim yapılabilir. "OÖ71, K)

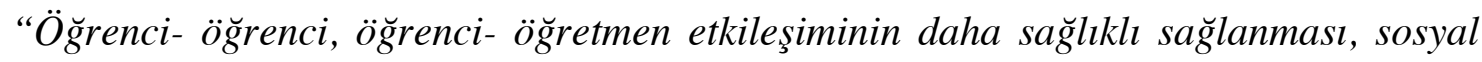
yeterliliklerinin düşük kalmaması için uzaktan eğitim belli bi seviyeden sonra yapılamaz." $(\mathrm{OÖ} 81, \mathrm{E})$

"Zorunlu olarak yaşanan bu süreçte eğitim materyali herkese eşit ve adil olarak dă̆ıtılamıyorsa, öğrencinin yanında bulunan yetişkinin farklı işlerinin olması, ilgilenememesi, bireysel destek verilmemesi bu süreci anlamsızlaştırıyor.” (OÖ101, K)

“Okul öncesinde etkileşim ne kadar az olursa gelişimde o oranda az olacaktır. Bu yüzden uzaktan ĕ̆itimin işlevsel olduğunu düşünmüyorum.” (OÖ110, K)

“Bu yaş grubunda mutlaka veli devreye girmesi gerekiyor. Velilerde çalıştı̆̆ için uğraşmak istemiyorlar. Ayrıca bu yaş grubunda dönüt almak çok zor olduğu için yapılmasının çok faydası olmadı ̆̆ını düşünmekteyim.” (OÖ135, K)

“Erken çocuklukta yüz yüze iletişim, sosyalleşme çok önemlidir bu da uzaktan bir şekilde mümkün değildir. O yaştaki bir çocuk keşfederek görerek öğrenir. Bunu online bir şekilde kazandırmak çok zor” (OÖ162, K)

“Uzaktan e ğitim birebir ĕ̆itim etkisini asla göstermez özellikle ilkokul çă̆ı çocuklarının ögrenme, sosyalleşme ve sosyal davranışsal gelişimi adına. Ayrıca yurdumuzda her öğrenci ve öğretmenin fiziki teknik imkanları uzaktan ĕgitime erişime engel olmaktadır. Yapılamaz demiyorum yapılır ama etkisi çok azdır.” (OÖ189, K)

\section{Okul Öncesi Öğretmenlerinin Uzaktan Eğitimde Veli Katılımına İlişkin}

\section{Düşünceleri}

Araştırmanın ikinci alt probleminde okul öncesi öğretmenlerinin uzaktan eğitimde velilerden bekledikleri desteklere ilişkin görüşleri ve deneyimleri incelenmiş olup, elde edilen kodlar şekil 4'teki gibi gösterilmektedir. 


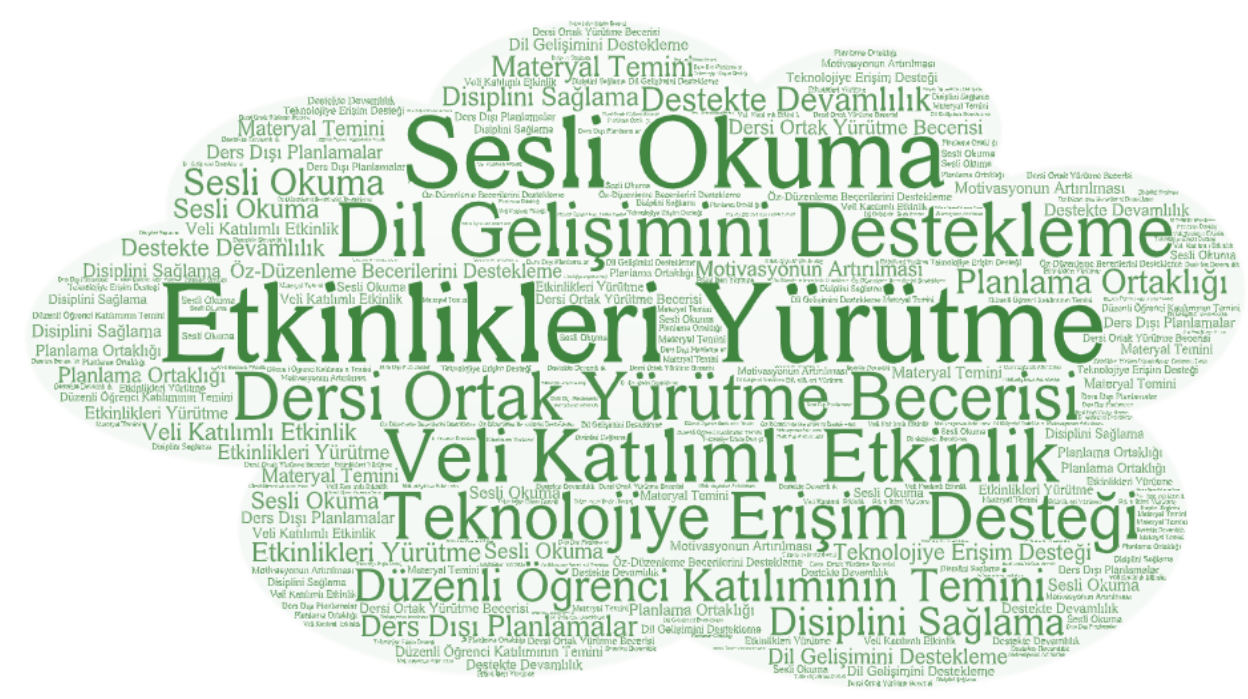

Şekil 4. Okul öncesi öğretmenlerinin uzaktan eğitime veli desteğine ilişkin kodların dağılımı

Şekil 4'te görüldüğüu üzere, uzaktan eğitimde okul öncesi öğretmenleri velilerden en çok etkinlikleri yürütme konusunda destek bekledikleri ortaya çıkmıştır. Tablo 5 'te bu görüşlerden elde edilen kodların birleşmesiyle elde edilen temalar yer almaktadır.

\begin{tabular}{|c|c|c|c|}
\hline \multicolumn{4}{|c|}{$\begin{array}{l}\text { Tablo } 5 \\
\text { Okul Öncesi Öğretmenlerinin Uzaktan Ĕ̆itimde Veli Katılımına İlişkin Düşünceleri }\end{array}$} \\
\hline Temalar & Kodlar & f (Kod Sayısı) & $\%$ \\
\hline \multirow[t]{6}{*}{ Ebeveyn Temelli Destekler } & Devamlılık & 17 & 5,6 \\
\hline & Materyal Temini & 15 & 4,9 \\
\hline & Motivasyon & 14 & 4,6 \\
\hline & Ebeveyn Katılımlı Etkinlik & 24 & 7,9 \\
\hline & Dersi Ortak Yürütme Becerisi & 26 & 8,6 \\
\hline & Düzenli Katılımın Temini & 22 & 7,2 \\
\hline \multirow[t]{2}{*}{ Gelişim Temelli Destekler } & Dil Gelişimini Destekleme & 35 & 11,5 \\
\hline & Öz-Düzenleme Becerilerini Destekleme & 15 & 4,9 \\
\hline Teknoloji Temelli Destekler & Teknolojiye Erişim Desteği & 26 & 8,6 \\
\hline \multirow[t]{5}{*}{ Öğretmen Rolü Temelli Destekler } & Planlama Ortaklığı & 16 & 5,3 \\
\hline & Etkinlikleri Yürütme & 39 & 12,8 \\
\hline & Ders Dışı Planlamalar & 16 & 5,3 \\
\hline & Sesli Okuma & 21 & 6,9 \\
\hline & Disiplin Sağlama & 18 & 5,9 \\
\hline Toplam & & 304 & 100 \\
\hline
\end{tabular}


Okul öncesi öğretmenlerinin yaşanan bu uzaktan eğitim sürecinde veli-öğretmen işbirliği kapsamında velilerin neler yapması gerektiğini belirten görüşlerini incelediğimizde, öğrencinin derse katılımını takip etmelerini, uzaktan eğitim dersleri için gerekli araç-gereçleri evde hazır bulundurmalarını, öğrenci ile birlikte gerekli motivasyona sahip olmaları gerektiğini, öğretmenler birlikle eş zamanlı dersi yürütebilme becerilerine sahip olmaları, çocukların dil gelişimlerine destek olmalarını, çocukların ders için gereken teknolojik araçlara ulaşımını sağlamalarını, dersleri beraber planlamayı, etkinlikleri çocukların yapıp yapmadığını kontrol etmelerini, ders dışı çocuğu aktif tutan etkinlikler planlamalarını, gün içerisinde çocuklara sesli okumalar yapmalarını ve uzaktan eğitim dersleri sürecinde gereken disiplini sağlamalarını söyleyen ifadeler yer almaktadır. Okul öncesi öğretmenlerinin bu görüşlerinden bazıları aşağıda gösterilmiştir:

"Bilgiye ve araştırmaya açık bir biçimde öğretmenlerin plan ve programına dahil olabilirler." (OÖ1, K)

"Velilerimi belirli aralıklar ile motive etmem gerekti. Süreçteki önemlerinden bahsettim sık sık. Okul öncesi e ğitimin önemi hakkında bilgilendirme ve evdeki doğadaki materyaller ile etkinlik yapabilme konusunda ĕgitim verilebilir.” (OÖ7, K)

“Ebeveynlerin eğitimli, ögrretmen ya da lisans ve devamından mezun olanların desteğini fazlası ile gördüm. Ancak diğerleri sadece gönder bakarı. Geri dönüt istemeyin. Ŭ̆raşamıyoruz, şekilde bir yaklaşım sergiledi. Bakanlık düzeyinde bir zorunluluk ve "notla de ğerleme” olduğunda velilerde sürece katılacaktır.” (OÖ28, K)

“Öğretmenlerini takip edebilirler. Kitaplar okuyup çocuklara örnek olabilirler. Evde neler yapılabilece ği konusunda fikirler üretip programlayabilirler. Tvden, instagramdan uzmanlarl dinleyebilirler.” (OÖ65, K)

“Ebeveynler verilen çalışmaları titizlikle takip etmeli ve çocuğuna da bunu göstermelidir. Bu şekilde son güne kadar çalıştığım velilerim var ve öğrencilerim evde dahi çok kaliteli vakitler geçirdiler sabah kalktıklarında etkinliklerimizi yapalım diyerek uyanan ögrencilerim oldu bunun etkisinin ben kadar velimde de olduğunu düşünüyorum. Ĕ̆itim sadece ögretmen ve öğrenci de ğildir tüm kurum kuruluş ve kişilerin çabast iste ği ve titizliğini gerektiriyor. Bunu başarabilen ülkeler ise gelişiyor.” (OÖ94, K)

“Öğrenciye sınıf ortamı oluşturulamasa bile muhakkak ona özel bir ders köşesi hazırlanmalı. Muhakkak ders takibi yapılmalı. Yalnızca pandemi döneminde değil her durumda öğrenci iletişimde olup ders dışı birlikte verimli zaman geçirme, ailecek kitap okuma, film seyretme vs gibi etkinlikler yapılmalı.” (OÖ123, E) 
“Öğretmenle iş birliği halinde olmaları süreci iyi yönetmeleri gerektiğinin farkında olmaları ve kesinlikle çocuklarına zaman ayırmaları gerekli.” (OÖ132, K)

“Telefon üzerinden iletişim ăglarını aktif kullanmaları gerekir. Öğretmen ile etkili iletişim kurarak çocuklarının ö̆grenme becerileri diri tutulabilir. Öğrencilerin okul ve öğrenme sürecinden bă̆ımsızlaşmamalı ebeveynlerin sorumluluğunda bulunmaktadır bu süreçte. Öğretmenin verdiği sorumlulukları çocuklarının yapması içim destek olmaları gerekiyor.” (OÖ176, K)

“Çocuklarla beraber derslerimize sessizce katılabilirler, dinleyip ders islenişi konusunda fikir edinebilirler. Verdiğimiz görevlerin yapılıp yapılmadı̆̆ını (şiir ezberleme, defterlerin düzenli kullanımı, görev ve sorumlulukların kontrolü sağlamalılar.” (OÖ211, E)

“Çocuklarıyla öğretmen olmadan, dikte etmeden evde oyun oynayarak, ihtiyaçlarına saygı göstererek, bir birey olarak temel değerlerine ve isteklerine saygı duymaları gerekmektedir. Önem verilen çocuk başarma duygusunu daha hızlı keşfedebilecektir." (OÖ232, K)

\section{Sonuçlar}

Yapılan araştırmanın bulguları incelendiğinde, okul öncesi öğretmenlerinin uzaktan eğitime ilişkin genel görüşlerinin çoğunlukla olumsuz ifadelerden oluştuğu görülmektedir. Uzaktan eğitimin özellikle okul öncesi çocuklarında istenen düzeyde bir etki bırakmadığı, çocukların işlenen derslere karşı odaklanma sorunu yaşadığını, çocukların gelişimlerini takip etmenin güç olduğunu, derslerin plan dâhilinde ilerleyemediğini, dersin en önemli ihtiyaçlarından biri olan dijital araçların eksikliği, ortaya çıkan fazla iş gücü gerekliliği, velilerden kaynaklanan sorunlar ve sosyalleşme eksikliği bu sürece dair okul öncesi öğretmenlerinin genel görüşleri olarak yer almaktadır. Covid-19 pandemisinin tüm dünyayı etkisi altına aldığı andan itibaren dünyanın birçok ülkesi eğitim-öğretim faaliyetlerine çevrimiçi araçlarla devam etme kararı almış, bunun sonucunda uygulamaya konan bu çevrimiçi eğitimi ve etkilerini belirleme amacı taşıyan araştırmalar yapılmaya başlanmıştır. Dayal ve Tiko'nun (2020) yaptığı araştırma incelendiğinde, Covid-19 pandemi sürecinde okul öncesi öğretmenlerinin bu dönemde çeşitli kaygılar yaşadıkları bulgularına erişilmektedir. Okul öncesi öğretmenleri çocukların yeterli sağlıklı ve güvenli bir ortamda bulunmaları gerektiğine ilişkin düşüncelere rastlanmaktadır. Bununla beraber alanyazında Covid-19 pandemisi dahilinde yapılan araştırmaların sonuçları incelendiğinde, sonuçların yapılan bu araştırmanın bulgularıyla çeşitli benzerlikler gösterdiği görülmektedir (Bakioğlu ve Çevik, 2020; Erbaş, 
2021; Sarı ve Nayır, 2020; Yurtbakan ve Akyıldız, 2020). Örneğin, Sarı ve Nayır (2020) Covid19 pandemi sonrasında UNESCO, Dünya Bankası ve Reimers ve Schleicher tarafından eğitim hakkında hazırlanan üç rapora ilişkin yaptıkları incelemede, dünya genelinde pandemiden kaynaklı ortaya çıkan uzaktan eğitime karşı öğretmenlerin ve velilerin hazırlıksız yakalandıklarını, uzaktan eğitimi sürdürmede zorlukların yaşandığını, toplumdan soyutlanmalara neden olduğunu, program içeriklerinin ve teknolojik altyapıların yetersiz olduğunu, öğrenmede kayıpların ortaya çıktığını, fırsat eşitsizliğinin daha da arttığını ve velilerle iletişim noktasında ciddi sorunların olduğunu belirlemişlerdir. Yurtbakan ve Akyıldız'ın (2020) çalışmasında da uzaktan eğitimde öğretmen ve öğrenciler arasında yeterli etkileşimin olmaması, öğrencilerde var olan bireysel farklılıkların gözetilememesi, öğrencilerin çoğunlukla dinleyen durumunda kalıp pasif olmaları, öğrencilerin motivasyonlarının düşük olması ve ders sürelerinin yetersizliği uzaktan eğitimin ortaya çıkardığı olumsuzluklar olarak belirtilmiştir.

Okul öncesi dönemde çocukların aktif bir katılımcı olarak eğitim-öğretim etkinliklerine katılması bilişsel, duyuşsal ve devinişsel gelişimleri açısından son derece önemlidir. Yapılan araştırmada çocukların motor becerilerin gelişimine, sosyal-duygusal gelişimlerine, özbakım becerilerinin kazanılmasına, iletişim becerilerine olumsuz yansıyabileceği öğretmenler tarafından dile getirilmiştir. Yapılan bu çalışmada öğretmenlerin velilerden bu konularda çocuklarının gelişimlerine katkıda bulunmalarını istedikleri belirlenmiştir. Benzer şekilde, Kadan, Aysu ve Aras (2020) yaptıkları araştırmada, okul öncesi dönemdeki çocuklara özbakım becerilerinin kazandırılması, hareket ve oyun ihtiyaçlarının karşılanması ve akranlarıyla nasıl iletişim kuracakları türünden becerilerin mutlaka kazandırılması gerektiği, yaşanan bu Covid-19 pandemi sürecinde okul öncesi dönemde olan çocuklara karşı velilerin neler yapması gerektiğini belirlemişlerdir. Buna göre, velilerin mutlaka çocuklarının pandemi ile ilgili ne düzeyde bilgiye sahip olduklarını ve varsa yanlış bilgilerini düzeltmeleri gerektiği, oyunla veya çeşitli hikâyelerle süreci anlatmaları, korku ve kaygılarını önemsemelerini tavsiye etmişlerdir.

Ekran bağımlılığı, yaşanan Covid-19 pandemi sürecinde araştırmacılar tarafından en çok tespit edilen kaygılardan biridir (Akkaş- Baysal, Ocak ve Ocak, 2020; Başaran ve Aksoy, 2020; Kadan, Aysu ve Aras, 2020; Mart ve Kesicioğlu, 2020). Son y1llarda okul öncesi dönemde çocukların yaşadığı dijital bağımlılık türlerine, bunların açıklamalarına ve alınması gereken önlemlere ilişkin çalışmalarda artışın yaşandığı görülmektedir (Almourad, McAlaney, Skinner, Pleva ve Ali, 2020; Erbaş, 2020; Hazar ve Hazar, 2017, Smahel, Wright ve Cernikova, 2015; Wolfling, Beutel, Dreier ve Muller, 2014). Geçen bir yıl boyunca, bu konudaki kaygıların daha 
da arttı̆̆ı, eğitim öğretimde söz sahibi olan bütün paydaşların bu konuda tedbirler almaları gerektiği çalışmalarda sıklıkla tavsiye edilen bir durum halini almıştır (Bayburtlu, 2020; Gökler ve Turan, 2020; Kazan-Kızılkurt ve Dilbaz, 2020; Küçük-Biçer ve İlhan, 2020;).

Ailelerin de bu süreçte çocukların eğitimlerine katkısı her zamankinden daha fazla olduğu bilinen bir gerçektir. Pandemi öncesi yapılan araştırmalar incelendiğinde, ailelerin okul öncesi eğitim sürecinde aktif katılımının çocuğun gelişimine ve eğitimine katkı sağladığını gösteren çalışmalar da alanyazında yer almaktadır (Aslanargun, 2007; Atakan, 2010; Çakmak, 2010; Ekinci-Vural, 2012; Göktaş, 2015; Kartal, 2005). Yapılan bu çalışmada da ailelerin ailelerin pandemi sürecinde etkin katılım göstermesinin öğretmenin işini kolaylaştırdığını gösteren bulgulara rastlanmaktadır.

\section{Öneriler}

Elde edilen bu sonuçlardan yola çıkılarak, okul öncesi eğitimde öğretmenlerin, velilerin ve yetkililerin yapması gerekenlere ilişkin aşağıdaki önerilerde bulunabiliriz;

1. Öğrencilerin daha aktif olacağı ve katılımı artırmaya yönelik etkinlikler hazırlayarak, çocuklarda uzaktan eğitime karşı çocuklarda oluşan ilgisizliği ve odaklanma sorunları en aza indirgenebilir.

2. Öğretmen ve velilerde eksik olduğu ortaya çıkan, teknolojiyi eğitim-öğretim amacıyla mümkün olduğunca kaliteli kullanabilme becerilerini arttırmaya yönelik eğitimler verilebilir.

3. Veli-öğretmen işbirliğini artıracak, kimi zamanlarda ortaya çıkan veli ilgisizliğini azaltacak, velileri bilinçlendirmeye yönelik eğitimler planlanabilir.

4. Özellikle okul öncesi çocuklarının gelişim düzeylerine uygun olarak yazılımların hazırlanması veya var olan yazılımların bu ihtiyaçlar doğrultusunda güncellenmesine öncelik verilebilir.

5. Ortaya çıkması muhtemel ekran bağımlılığına karşı ders süreleri çocukları minimum seviyede ekranda tutacak şekilde planlanabilir.

6. Ailelere evde ders dışı yapılabilecek, çocukların yapmaktan zevk alacağı etkinliklere dair bilgiler verilebilir.

7. $\mathrm{Bu}$ süreçte uygulanan uzaktan eğitimde öğretmen-veli işbirliği içerisinde öğretmenle beraber etkinliklerin planlayıcısı ve uygulayıcısı olarak velilerden yararlanmak, çocukların yaşayabileceği olumsuzlukları azaltacak tedbirlerden biri olabilir. 


\section{Kaynakça}

Akkaş Baysal, E, Ocak, G. \& Ocak, İ. (2020). Covid-19 salgını sürecinde okul öncesi çocuklarının EBA ve diğer uzaktan eğitim faaliyetlerine ilişkin ebeveyn görüşleri. Uluslararası Sosyal Bilimler Ĕ̈itimi Dergisi, 6 (2), 185-214. https://doi.org/10.47615/issej.835211 .

Almourad, M. B., McAlaney, J., Skinner, T., Pleva, M., \& Ali, R. (2020). Defining digital addiction: Key features from the literature. Psihologija, 53(3), 237-253. https://doi.org/10.2298/ PSI191029017A.

Aslanargun, E. (2007). Okul-aile işbirliği ve öğrenci başarısı üzerine bir tarama çalışma. Manas Üniversitesi Sosyal Bilimler Dergisi, 9(18), 119-135.

Atakan, H. (2010). Okul Öncesi Eğitiminde Aile Katılımı Çalışmalarının Öğretmen ve Ebeveyn Görüşlerine Göre Değerlendirilmesi (Yayımlanmamış yüksek lisans tezi). Çanakkale Onsekiz Mart Üniversitesi Sosyal Bilimler Enstitüsü, Çanakkale.

Bakioğlu, B., \& Çevik, M. (2020). COVID-19 pandemisi sürecinde fen bilimleri öğretmenlerinin uzaktan eğitime ilişkin görüşleri. Turkish Studies, 15(4), 109-129. https://doi.org/10.7827/TurkishStudies.43502

Başaran, M., \& Aksoy, A.B. (2020). Anne-babaların korona-virüs (Covid-19) salgını sürecinde aile yaşantılarına ilişkin görüşleri, Uluslararası Sosyal Araştırmalar Dergisi, 13(71), 668-678.

Bayburtlu, Y.S. (2020). Covid-19 pandemi dönemi uzaktan eğitim sürecinde öğretmen görüşlerine göre Türkçe eğitimi. Turkish Studies, 15(4), 131-151. https://dx.doi.org/10.7827/TurkishStudies.44460 .

Büyüköztürk, Ş., Kılıç-Çakmak, E., Akgün, Ö.E., Karadeniz, Ş., \& Demirel, F. (2020). Bilimsel araştırma yöntemleri (28. bask1). Pegem Akademi.

Can, E. (2020). Coronavirüs (Covid-19) pandemisi ve pedagojik yansımaları: Türkiye'de açık ve uzaktan eğitim uygulamaları. Açıöğretim Uygulamaları ve Araştırmaları Dergisi, 6(2), 11-53.

Creswell. J.W. (2012). Educational research: Planning, conducting, and evaluating quantitative and qualitative research. Pearson.

Çakmak, Ö.Ç. (2010). Okul öncesi eğitim kurumlarında aile katılımı. Abant İzzet Baysal Üniversitesi Sosyal Bilimler Dergisi, 1(20). 1-17.

Çalışkan, Ö., \& Özbay, F. (2015). 12-14 yaş aralığındaki ilköğretim öğrencilerinde teknoloji kullanımı eksenli yabancılaşma ve anne baba tutumları: Düzce ili örneği. Journal of International Social Research, 8(39), 441-458. 
Daniel, S. J. (2020). Education and the Covid-19 pandemic. Prospects,49, 91-96.

Darling-Hammond, L., \& Hyler, M. E. (2020). Preparing educators for the time of COVID... and beyond. European Journal of Teacher Education,43(4), 457-465. https://doi.org/10.1080/02619768.2020.1816961

Dayal, H. C., \& Tiko, L. (2020). When are we going to have the real school? A case study of early childhood education and care teachers' experiences surrounding education during the COVID-19 pandemic. Australasian Journal of Early Childhood, 45(4), 336-347.

Demir, F., \& Özdaş, F. (2020). Covid-19 sürecindeki uzaktan eğitime ilişkin öğretmen görüşlerinin incelenmesi. Milli Eğitim Dergisi, 49(1), 273-292. https://doi.org/10.37669/milliegitim.775620

Demir, S., \& Özmantar, F. M. (2013). Teknoloji destekli matematik öğretiminde pedagojik prensipler. M. Doğan \& E. Karakırık (Ed.), Matematik eğitiminde teknoloji kullanımı içinde (s.1-25). Nobel Yayıncılık.

Ekinci-Vural, D. (2012). Okul öncesi eğitimin ilköğretime etkisinin aile katılımı ve çeşitli değişkenler açısından incelenmesi (Yayımlanmamış doktora tezi). Dokuz Eylül Üniversitesi Eğitim Bilimleri Enstitüsü, İzmir.

Erbaş, Y.H. (2020). Erken çocukluk döneminde dijital bağımlılık. R.F. Ağmaz ve F. Ergüleç (Eds.), Erken çocukluk eğitiminde dijital teknoloji ve ögrrenme içinde (s. 93-107). Pegem Akademi.

Erbaş, Y.H. (2021). Covid-19 salgını döneminde eğitim: İlkokuma yazma öğretiminde karş1laşılan sorunlar ve çözüm önerileri. Ana Dili Eğitimi Dergisi, 9(2), 360-380.

Fauzi, I., \& Khusuma, I. H. S. (2020). Teachers' elementary school in online learning of COVID-19 pandemic conditions. Jurnal Iqra': Kajian Ilmu Pendidikan, 5(1), 5870. https://doi.org/10.25217/ji.v5i1.914

Garbe, A., Ogurlu, U., Logan, N., \& Cook, P. (2020). Parents' experiences with remote education during COVID-19 school closures. American Journal of Qualitative Research, 4(3), 45-65. https://doi.org/10.29333/ajqr/8471

Gökler, M., \& Turan, Ş. (2020). Covid-19 pandemisi sürecinde problemli teknoloji kullanımı. ESTÜDAM Halk Să̆lı̆̆ Dergisi,5, 108-114.

Göktaş, İ. (2015). Aile katılımı ve sosyal beceri eğitimi programlarının tek başına ve birlikte 4-5 yaş çocuklarının sosyal becerileri ve anne-çocuk ilişkileri üzerindeki etkisinin incelenmesi (Yayımlanmamış yüksek lisans tezi). Pamukkale Üniversitesi Eğitim Bilimleri Enstitüsü, Denizli. 
Hazar, Z., \& Hazar, M. (2017). Çocuklar için dijital oyun bağımlılı̆̆ı ölçeği. Journal of Human Sciences, 14(1), 203-216.

İnan, H. Z. (2020). Covid-19 pandemi sürecinde okul öncesi eğitimin yeniden yapılandırılması. Milli Eğitim Dergisi,49(1), 831-849. https://doi.org/10.37669/milliegitim.754307

Kadan, G., Aysu, B., \& Aral, N. (2020). Covid 19 sürecinde çocuklar: Gelişimsel ihtiyaçlar ve öneriler. Çankırı Karatekin Üniversitesi Sosyal Bilimler Enstitüsü Dergisi, 11(2), 360-379.

Kartal, H. (2005). Erken çocukluk eğitim programlarından anne çocuk eğitim programının 6 yaş grubundaki çocukların bilişsel gelişimlerine etkisi (Yayınlanmamış Doktora Tezi). Uludağ Üniversitesi Sosyal Bilimler Enstitüsü, Bursa.

Kazan-Kızılkurt Ö., \& Dilbaz N. (2020). COVID-19 pandemisinde bağımlılık. Coşar B. (ed.), Psikiyatri ve COVID-19 içinde (s.59-65). Türkiye Klinikleri.

Kim, J. (2020). Learning and teaching online during Covid-19: Experiences of student teachers in an early childhood education practicum. International Journal of Early Childhood, 52(2), 145-158.

Korkmaz, G., \& Toraman, Ç. (2020). Are we ready for the post-COVID-19 educational practice? An investigation into what educators think as to online learning. International Journal of Technology in Education and Science (IJTES), 4(4), 293-309. https://doi.org/10.46328/ijtes.v4i4.110

Küçük-Biçer, B., \& İlhan, M. (2020). Covid-19'un çocukların sağlığı üzerine etkisi. Gazi Să̆lık Bilimleri Dergisi, Gazi Să̆lık Bilimleri Dergisi Özel Sayı, 103-111.

Mart, M., \& Kesicioglu, O.S. (2020). Parents' opinion to play at home during Covid-19 pandemic. Turkish Studies, 15(4), 945-958. https://doi.org/10.7827/TurkishStudies.44381

Reimers, F. M., \& Schleicher, A. (2020). A framework to guide an education response to the COVID-19 Pandemic of 2020. OECD Report. 30 Aralı 2020 tarihinden https://oecd.dam-broadcast.com/pm_7379_126_126988-t631xosohs.pdf adresinden alınmıştır.

Sarı, T., \& Nayır, F. (2020). Pandemi dönemi eğitim: sorunlar ve firsatlar. Turkish Studies, 15(4), 959-975. https://dx.doi.org/10.7827/TurkishStudies.44335

Sayan, H. (2016). Okul öncesi eğitimde teknoloji kullanımı. 21. Yüzyılda Eğitim ve Toplum Ĕgitim Bilimleri ve Sosyal Araştırmalar Dergisi, 5 (13), 67-83.

Schweinhart, L.J. (2020). Günümüzde erken çocukluk eğitimi ve müfredat modelleri. E.A. Acar (Ed.), Erken çocukluk eğitimi içinde (s.1-12). Nobel Akademik. 
Sirem, Ö., \& Baş, Ö. (2020). Okuma güçlüğü olan ilkokul öğrencilerinin Covid-19 sürecinde uzaktan eğitim deneyimleri. Turkish Studies, 15(4), 993-1009. https://dx.doi.org/10.7827/TurkishStudies.43346

Smahel, D., Wright, M. F., \& Cernikova, M. (2015). The impact of digital media on health: children's perspectives. International Journal of Public Health, 60(2), 131-137. https://doi.org/10.1007/s00038-015-0649-z

Tarkoçin, S., Alagöz, N. \& Boğa, E. (2020). Okul öncesi dönem çocuklarının pandemi sürecinde (COVID19) davranış değişiklikleri ve farkındalık düzeylerinin anne görüşlerine başvurularak incelenmesi. Turkish Studies, 15(6), 1017-1036. https://dx.doi.org/10.7827/TurkishStudies.44338

UNESCO. (2020). Startling digital divides in distance learning emerge. UNESCO. 23 Aralık 2020 tarihinde https://en.unesco.org/news/startling-digital-divides-distance-learningemerge adresinden alınmıştır.

Wolfling, K., Beutel, M. E., Dreier, M., \& Muller, K. W. (2014). Treatment outcomes in patients with internet addiction: A clinical pilot study on the effects of a cognitive-behavioral therapy program. BioMed Research International, 2014, 1-8. https://doi.org/10.1155/2014/425924

World Health Organization. (2020). Coronavirus disease (COVID-19) Pandemic. World $\begin{array}{lllll}\text { health } & \text { Organization. } & 25 & \text { Aralk } & 2020\end{array}$ https://www.who.int/emergencies/diseases/novel-coronavirus-2019 adresinden alınmıştır.

Yıldırım, A., \& Şimşek, H. (2018). Sosyal bilimlerde nitel araştırma yöntemleri. Seçkin Yayınc1lı.

Yurtbakan, E., \& Akyıldız, S. (2020). Sınıf öğretmenleri, ilkokul öğrencileri ve ebeveynlerin Covid-19 izolasyon döneminde uygulanan uzaktan eğitim faaliyetleri hakkındaki görüşleri. Turkish Studies, 15(6), 949-977. https://dx.doi.org/10.7827/TurkishStudies.43780 


\section{Yazarlar Hakkında}

\section{Ebru AKTAN ACAR}

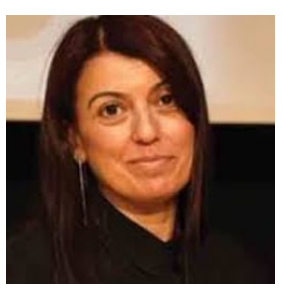

2001 yılında Marmara Üniversitesi Eğitim Bilimleri Enstitüsü Okul Öncesi Eğitimi Bilim Dalı'nda doktorasını tamamladı. 1997 yılında Çanakkale Onsekiz Mart Üniversitesi Eğitim Fakültesi İlköğretim Bölümü Okul Öncesi Öğretmenliği Anabilim Dalı’nda Araştırma Görevlisi olarak görev yapmaya başladı. Halen aynı üniversitede Temel Eğitim Bölümü Okul Öncesi Eğitimi Anabilim Dalı’nda Profesör Dr. olarak görev yapmaktadır. Ayrıca ÇABA Çok Amaçlı Erken Çocukluk Eğitimi Merkezi’nin (ÇABAÇAM) Proje Koordinatörlüğü’nü yürütmektedir. Erken okuma becerileri ve okuma-yazmaya hazırlık çalışmaları, dünyadaki erken çocukluk eğitimi model ve yaklaşımları, barış eğitimi ve farklılıklara saygı konuları çalışma alanlarıdır.

Posta adresi: $\quad$ Çanakkale Onsekiz Mart Üniversitesi, Anafartalar Kampüsü, Eğitim Fakültesi Tel (İş): $\quad$ +902862180018-3611

Eposta: $\quad$ ebru.aktan@yahoo.com.tr

URL: $\quad$ https://avesis.comu.edu.tr/1347

\section{Yahya Han ERBAŞ}

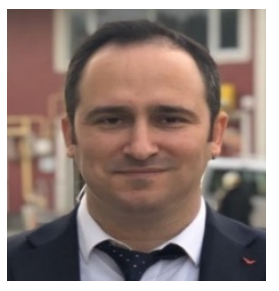

2017'de doktora eğitimini Indiana Üniversitesi Eğitim Fakültesi Okuryazarlık, Kültür ve Dil Eğitimi alanında tamamladı. 2018'de Çanakkale Onsekiz Mart Üniversitesi Eğitim Fakültesi Temel Eğitim bölümünde göreve başlamıştır. 2020 yılından itibaren Çanakkale Onsekiz Mart Üniversitesi Eğitim Fakültesi-Eğitim Bilimleri bölümünde doktor öğretim üyesi olarak görev yapmaktadır. Okuma yazma eğitimi, çokkültürlü eğitim, öğretmen eğitimi, nitel araştırma yöntemleri ve çocuk edebiyatı alanlarında çalışmalarına devam etmektedir.

Posta adresi: $\quad$ Çanakkale Onsekiz Mart Üniversitesi, Anafartalar Kampüsü, Eğitim Fakültesi Tel (İş): $\quad$ +902862180018-3665 Eposta: $\quad$ yahyahan@gmail.com

\section{Mustafa Yunus ERYAMAN}

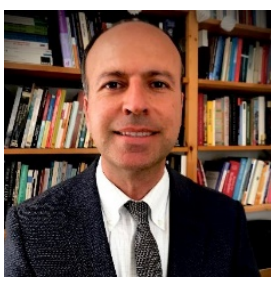

2006 y1lında Illinois Üniversitesi Urbana-Champaign'de doktora eğitimini tamamlamıştır. Çanakkale Onsekiz Mart Üniversitesi Eğitim Fakültesi Temel Eğitim Bölümünde öğretim üyesidir. Dünya Eğitim Araştırmaları Birliği Başkanlığı ve Avrupa Komisyonu Değerlendirme Uzmanlığı görevlerini sürdürmektedir. Eğitim programları ve öğretim, sınıf öğretmenliği, eğitim felsefesi ve eğitim politikaları konularında çalışmaları devam etmektedir.

Posta adresi: Tel (İş): Eposta: URL: 